\title{
PA-X PEACE AGREEMENTS DATABASE: REFLECTIONS ON DOCUMENTING THE PRACTICE OF PEACEMAKING ${ }^{*}$
}

\author{
Sanja Badanjak \\ University of Edinburgh \\ ORCID: 0000-0003-4207-9696
}

(C) S.Badanjak, 2021

DOI: $10.20542 / 2307-1494-2021-2-24-42$

\begin{abstract}
Since its first release in the form of the PA-X Peace Agreements Database, the initial project undertaken by the University of Edinburgh's Political Settlements Research Programme has seen four more data releases. Multiple data and visualisation projects stemmed from PA-X. The article provides an update to the initial introduction to the PA-X data and discusses the key lessons learned from the processes of data collection, analysis, and visualisation. This assessment is undertaken in two key areas: first, with regard to the process of "building" a dataset and database; second, with regard to the substantive findings and trends gleaned from the PA-X data on peace agreements and peace processes. The place and impact of this database in the context of peace and conflict studies are also assessed. Data resources pertaining to this field of inquiry are explored, with the focus on the ways in which the PA-X data can be used in conjunction with other datasets on peace and conflict. Finally, the future development of PA-X is addressed. It is argued that keeping up with the direction of the research literature in the field requires that the data on peace processes and peace agreements are better disaggregated, in terms of actors and groups signing deals, and in terms of spatial and temporal coverage of the signed peace deals.
\end{abstract}

Keywords peace agreements, peace and conflict datasets, data analysis, methodology, data visualisation, peace and conflict studies

\section{Название База данных РА-Х по мирным соглашениям: проблемы документиро- вания и фиксирования миротворческих практик}

Аннотация За годы, прошедшие после выхода первой базы данных по мирным соглашениям РА-Х, в развитие первоначального проекта Программы по исследованиям политических урегулирований Эдинбургского университета, было осуществлено еще четыре выпуска массивов данных. База РА-Х также

\footnotetext{
* PA-X is produced and maintained by the team at the University of Edinburgh Law School, based on the work of Professor Christine Bell (Bell C. On the Law of Peace: Peace Agreements and the Lex Pacificatoria. Oxford: Oxford University Press, 2008). Christine Bell is the principal investigator, the present author is data manager, and the remainder of the authors of the PA-X Codebook vitally contribute to the data management, production, and development process (Bell C., Badanjak S., Beaujouan J., Epple T. et al. PA-X Peace Agreements Database and Dataset. Version 5. - Edinburgh: Political Settlements Research Programme, University of Edinburgh, 2021). The PA-X Peace Agreements Database is an output of the Political Settlements Research Programme funded by UK's Foreign, Commonwealth and Development Office.

** Sanja Badanjak (Croatia) is a Post-Doctoral Research Fellow at the School of Law, University of Edinburgh, UK. Саня Баданджак (Хорватия) - научный сотрудник Школы права Эдинбургского университета, Великобритания.
} 
стала основой целого ряда проектов по сбору, кодификации, анализу и визуализации данных. Статья содержит обновленный обзор первоначальной методологии базы РА-Х и ключевых уроков, которые можно извлечь из процессов сбора, анализа и визуализации соответствующих данных. Этот анализ сосредоточен на двух областях: во-первых, на процессе создания базы и коллекций (рядов) данных, а во-вторых, на тех сущностных результатах, выводах и тенденциях, которые выявлены на основе изучения данных PA-X по мирным соглашениям и процессам мирного урегулирования. Также проведена оценка места и значения этой базы данных в контексте исследований мира и конфрликтов. Рассмотрены и другие, аналогичные научные ресурсы в этой области; особое внимание уделено тому, каким образом данные РА-Х могут быть использованы в сочетании с другими массивами данных о мире и конфрликтах. Наконец, намечены направления будущего развития базы данных РА-Х. Сделан вывод о том, что для того, чтобы соответствовать современному уровню исследований по проблемам мира и конфликтов, требуется более глубокая дезагрегация и детализация данных о мирных процессах и соглашениях, особенно в отношении акторов и группировок, являющихся участниками таких договоренностей, а также углубленный анализ пространственных и временных характеристик подписанных мирных соглашений.

Ключевые мирные соглашения, пакеты данных по проблемам мира и конфрликтов, слова анализ данных, методология, визуализация данных, исследования мира и конфрликтов

\section{Introduction}

In most armed conflicts, attempts to broker peace run parallel to ongoing conflict and contention. In fact, one may find that these attempts can start before conflict has broken out. However, for the most part, we see peace negotiations intensify or begin as the conflict continues or even escalates. Not all negotiations result in an agreement, and even those that do often reach a settlement that is inconclusive and fleeting. Nevertheless, the practice of peacemaking persists, even as it has undergone significant changes. These changes include fewer and fewer wide-ranging comprehensive agreements reached in large-scale internationalised peace processes and a turn of the third parties to alternative modes of negotiation, including increased reliance on local, geographically limited negotiations.

The PA-X Peace Agreements Database, based at the University of Edinburgh Law School and publicly available at www.peaceagreements.org, serves as a repository and data resource on this practice and the changes taking place therein. PA-X records all publicly available, formal, written, and signed instances of peace agreements reached in any significant armed conflict since 1990 and until present day. Since its first publication in 2018, PA-X has seen four additional releases, the most recent of which expanded the database to update it through June 2021 and contains a total of 1915 agreements. The PA-X datasets also include PA-X Gender ${ }^{1}$ and PA-X Local, ${ }^{2}$ both functioning as subdatabases of the main collection. While the database as a whole serves as an archive of formal agreements, it also endeavours to provide a database for day-to-day use by mediators and diplomats, as well as a qualitative and quantitative data source for social and political scientists, legal scholars, and other researchers.

This article provides a perspective on PA-X from within the PA-X team. It describes the database's core features and assesses the key points learned from the data 
collection process thus far. The main broader argument is that data resources available in the study of peace processes do not go far enough in providing detailed, micro-level data for social research. In order to support the expansion of knowledge and methodologies for the study of conflict dynamics and peace processes, the future iterations of this data resource need to be disaggregated, so that they relate to specific organised armed groups and state actors. They also need to be better defined in terms of geographic areas they pertain to, with improved geocoding and matching to subnational units.

Section II of the article describes PA-X, its main features, components, the process by which a signed agreement becomes part of the public database and datasets, and some lessons gleaned from the practice of providing research data. In Section III, the PA-X data are placed in context: the features that make PA-X distinct yet complementary to the other data resources on peace agreements are shown, and a brief overview of the use of PA-X in social science literature since the database's initial publication is provided. Finally, in Section IV, key lessons learned concerning the data on peace agreements and peace processes are assessed. The article concludes with plans for improvements of the PA-X Database.

\section{About PA-X}

The scope of the PA-X collection relies on a core definition of peace agreement as a "formal, publicly available document, produced after discussion with conflict protagonists and mutually agreed to by some or all of them, addressing conflict with a view to ending it". ${ }^{3}$ As a publicly available collection of 1915 formal and publicly available documents, PA-X serves as an archive of formal attempts to resolve interstate, intrastate, and local armed conflicts, covering the period from 1990 to present day.

Taking into account that many instances of agreements were concluded well after the end of actual fighting, an agreement is included in PA-X if it was signed after January 1,1990, and if the conflict that it addresses is ongoing or has ended at some point during 50 years prior to the signing of the agreement. Hence, we see in PA-X some agreements that somewhat stand out, as they formalize a settlement between the sides long after the war itself had ended. For instance, the 1990 Joint Statement of Confidence-Building Measures, including an Information and Consultation System and Safety Measures for Air and Maritime Navigation ${ }^{4}$ resolves outstanding issues from the Falklands war, even as the war itself ended in 1982. The 1990 Treaty on the Final Settlement with Respect to Germany (four plus two agreement) is at the tail end of this fifty-year cut-off, as it was signed 45 years after World War II had ended, forming a final agreement between Germany and the Allies, and making way for Germany's reunification. ${ }^{5}$

The two PA-X sub-databases, PA-X Gender ${ }^{6}$ and PA-X Local, ${ }^{7}$ contain subsets of the full PA-X data. PA-X Gender focuses on a more detailed coding of agreements that are in some way dealing with women, girls, and gender, while PA-X Local provides more detail on the agreements that refer to a relatively small geographic area, affected by localised conflict dynamics. Each of these sub-datasets can be accessed via its own website $^{8}$ where search tools and codebooks for them are also available. The PA-X Local sub-database features a slightly different approach from the main PA-X database, as it also takes into account the details of the locale and the process of negotiations and records the central longitude and latitude of the locales to which the agreements pertain. 
While PA-X in its current form was released in 2018, the database itself has roots in the data collected by Christine Bell and published a decade earlier. ${ }^{9}$ The agreements were compiled in a simple database that made available the core list of documents that fit the criteria of agreements, as well as the key issues they aimed to regulate. Work on the expanded and updated database started in 2015, with the initial version of the PA-X Gender data released in 2016 and the full PA-X made publicly available in 2018. Since 2018, PA-X has seen four additional updates, updated PA-X Gender dataset, and the addition of a collection of local agreements, PA-X Local. The team working on PA-X has relied and built upon these experiences to develop three additional resources: the "PeaceFem app", the dataset and tracker of ceasefires in a time of the Covid-19 pandemic, ${ }^{10}$ and the dataset of vaccination ceasefires. ${ }^{11}$

Table 1. PA-X frequencies, agreement/stage, and agreement/conflict levels

\begin{tabular}{|l|c|c|c|c|c|c|c|c|}
\hline & $\begin{array}{l}\text { Pre- } \\
\text { negotiation } \\
\text { or process } \\
\text { agree- } \\
\text { ments }\end{array}$ & $\begin{array}{c}\text { Substantive } \\
\text { but partial } \\
\text { agreements }\end{array}$ & $\begin{array}{l}\text { Substantive } \\
\text { comprehen- } \\
\text { sive } \\
\text { agreements }\end{array}$ & $\begin{array}{l}\text { Implementation } \\
\text { or renegotiation } \\
\text { agreements }\end{array}$ & $\begin{array}{c}\text { Rene- } \\
\text { wals }\end{array}$ & $\begin{array}{c}\text { Cease- } \\
\text { fires }\end{array}$ & Other & Total \\
\hline $\begin{array}{l}\text { Interstate } \\
\text { agree- } \\
\text { ments in } \\
\text { interstate } \\
\text { conflicts }\end{array}$ & 11 & 33 & 7 & 17 & 2 & 4 & 0 & 74 \\
\hline $\begin{array}{l}\text { Interstate } \\
\text { agree- } \\
\text { ments in } \\
\text { intrastate } \\
\text { conflicts }\end{array}$ & 63 & 5 & 55 & 91 & 9 & 21 & 0 & 244 \\
\hline $\begin{array}{l}\text { Intrastate } \\
\text { agree- } \\
\text { ments }\end{array}$ & 413 & 285 & 83 & 207 & 34 & 257 & 0 & 1279 \\
\hline $\begin{array}{l}\text { Local ag- } \\
\text { reements }\end{array}$ & 34 & 121 & 21 & 22 & 1 & 117 & 2 & 318 \\
\hline Total & 521 & 494 & 116 & 337 & 46 & 399 & 2 & 1915 \\
\hline
\end{tabular}

In the course of three years between the project's start and the initial release of PA-X database in 2018, Bell and the PA-X team worked on collecting agreements, digitising, translating, and topic-coding them and cooperated with the University of Edinburgh Information Services to develop the database and front-end search tools. All this was needed for PA-X to become an archive of documents, a repository of machinereadable texts of agreements, and qualitative and quantitative database and collection of datasets. Additionally, the front-end, i. e. the database website and search tools, had to be made accessible and user-friendly for practitioners, researchers, citizens, and diplomats. This meant that multiple formats and ways of approaching the data were needed. For example, historians may be interested in original documents, while mediators may wish to see a full collection of past agreements in a particular setting, and researchers may prefer to download a quantitative dataset that contains all markers that allow it to be merged with and compared to other datasets. The PA-X website currently allows accessing the data through all these ways. 
Since PA-X has such a broad scope and aims, it can encompass a wide variety of documents that differ in purpose, inclusion of relevant actors, and issues covered. The full collection is important as an overview of the variety in peacemaking activity, but for most research purposes the PA-X data ought to be disaggregated in line with their main focus of interest. Two categories in the PA-X data allow core classification of documents and can be relied on for meaningful disaggregation of the data: "Agreement/conflict level" and "Stage". Table 1 above shows the combinations of these two classifications and numbers of documents matching each combination.

"Agreement/conflict level" indicates the level of agreement (i. e. the signing sides) and the level of conflict to which the agreement pertains (see rows in Table 1). Two of the options are fairly straightforward: first, agreements between countries, aiming to resolve interstate conflict (interstate agreements), and second, those between the internal conflict parties in a civil war (intrastate agreements). The interstate agreements in interstate conflicts are archetypical agreements, representing the situation of countries that wage war and then reach a formal settlement. They are, however, relatively and increasingly rare, with only 74 having been publicly signed since 1990 . The agreements that contribute to resolving civil or intrastate wars have been the most common ones in the period since 1990, with 1279 such instances recorded in the database.

Figure 1. PA-X agreements, by stage

PA-X agreements, by stage

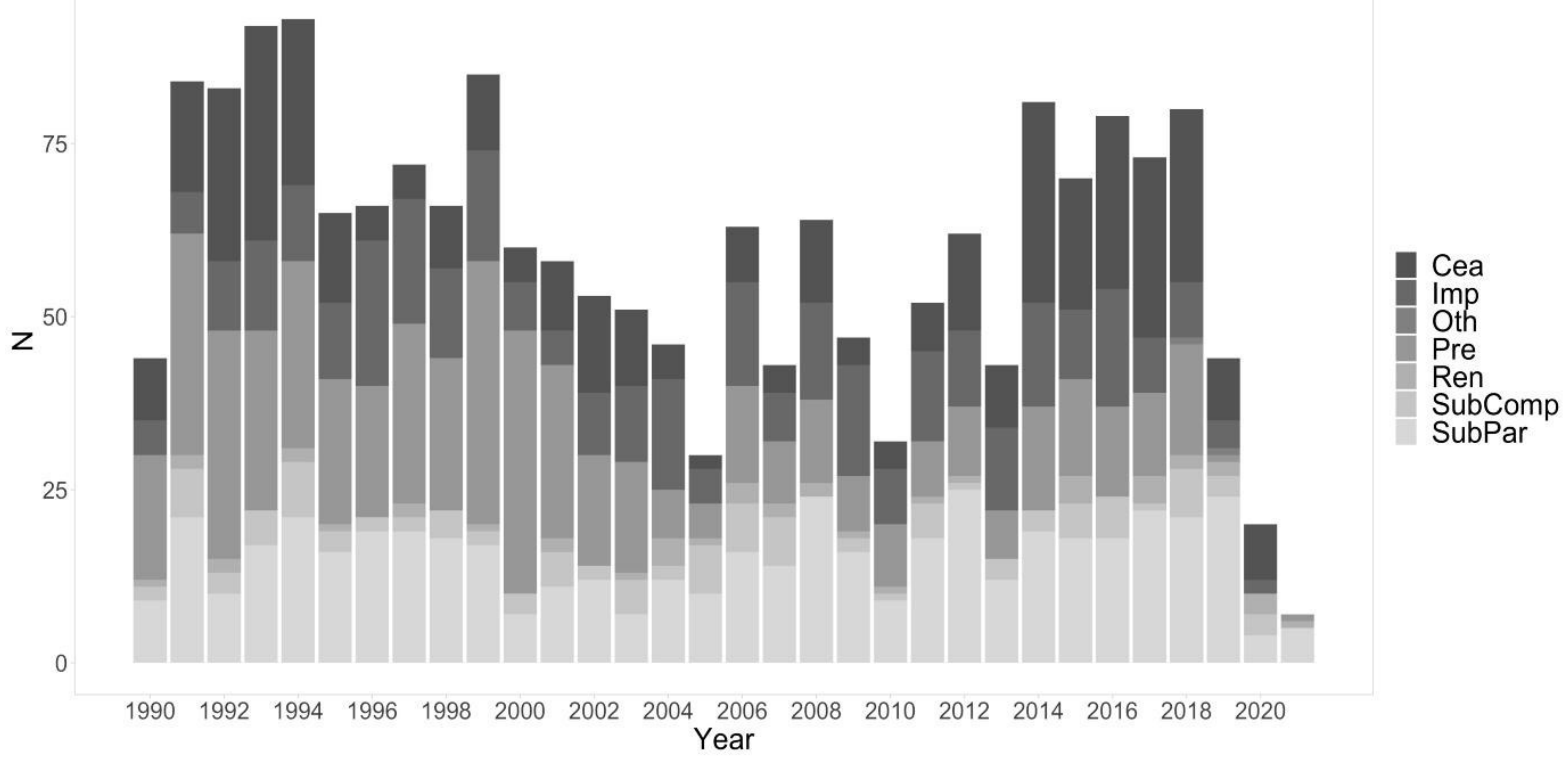

The two remaining types - interstate agreements in intrastate conflicts and local agreements - require additional explanation.

First, there are 224 interstate agreements in PA-X that deal with intrastate conflict. In these agreements, the main signatories are states or international organisations, though they are aimed at conflict resolution in one or more internal conflicts. For instance, many agreements signed in relation to the armed conflict in Bosnia and Herzegovina in the 1990s fall into this category, as they were signed not just by representatives of the parties directly engaged in fighting, but also by the neighbouring countries, the European Union, and others. These agreements are also common in the conflict in Northern Ireland, in Afghanistan, Liberia, Syria, and other cases. There are 
also rare agreements that are signed by multiple states as the main parties, but address multiple conflicts, best exemplified by agreements in the Great Lakes Region in Africa, such as the 2006 Pact on Security, Stability, and Development in the Great Lakes Region. ${ }^{12}$

Second, the category of "local agreements" was added to PA-X in its second release, in 2019, as it became clear that many of the agreements, and particularly some of the newer ones reached in the African and Middle Eastern regional contexts, were geographically limited, with application limited to towns, villages, or even neighbourhoods. These cases prompted rethinking of some agreements with a similarly limited spatial scope that had already been included in the PA-X data, such as humanitarian ceasefires between lower-ranked officers in Bosnia and Herzegovina (for example, on transporting the wounded persons). With new agreements added to the database, and existing ones reconsidered, the database now contains 318 agreements classified as local.

Figure 2. PA-X agreements, by agreement/conflict type

PA-X agreements, by agreement type

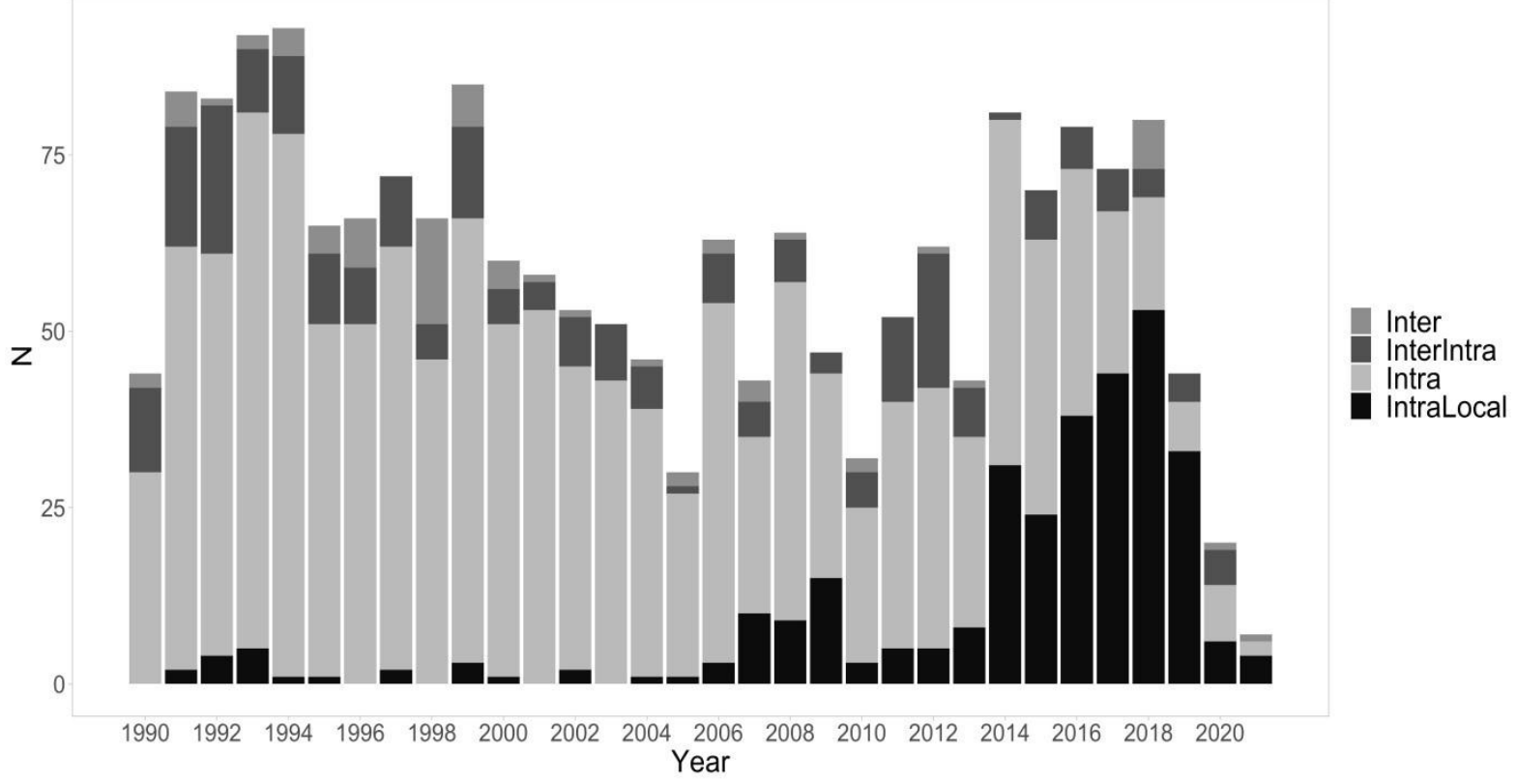

Agreement stage (see columns in Table 1) is the second of the core categories we rely on for basic categorisation of agreements in the PA-X database. C.Bell discusses the development of this category, placing its functional understanding at the forefront. ${ }^{13}$ This initial categorisation has been expanded for the purpose of PA-X, driven partly by the variation found in the agreements. The category is derived from the notion of successive peace agreements, signed over the course of a peace process and moving from agreements where the sides make arrangements for the talks themselves to ceasefires, substantive agreements, implementation agreements, and then renewal or extension agreements. This linear progression of a peace process is understood as an ideal-type in the Weberian sense, an abstraction that elucidates the concept of the peace process and sheds light on the functional components that comprise it: individual agreements that aim to resolve particular problems at particular points in the peace process. The reality of peace processes, however, rarely follows this ideal-type: the 
parties abandon some arrangements, wholly or partially, start new negotiations, recommit to older agreements, or return to fighting. Such processes, with multiple starts, stops, and setbacks, are shown in Figure 3 (see next section) that aggregates all peace processes in PA-X at once. It conveys a clear message that linear progression in peace talks is unexpected and rare.

Noting the agreement's stage is thus understood as identifying the agreement's core function and substantive scope. Most agreements address multiple types of issue, and PA-X designation of a "stage" refers to the document's primary aim. For instance, while many agreements contain some form of ceasefire provision(s), they are only designated as ceasefire agreements if reaching a ceasefire is the agreement's primary aim. As shown by Table 1, the classification introduced by the category of "stage" does create imbalances in the data, with some combinations of "stage" and "agreement/conflict level" producing very few cases of agreements.

Figures 1 and 2 show the over-time distribution of agreements in PA-X by their stage (see Figure 1) and agreement/conflict level (see Figure 2). Figure 2 in particular shows a relative decline in the number of agreements that aim to resolve the conflict as a whole - with fewer purely intrastate agreements being recorded and local agreements negotiated in their place. Together, these figures suggest that peace processes understood as attempts to bring major warring sides to the negotiating table may be on the wane: in Figure 1, the pre-negotiation agreements that should serve to kick off a peace process, are fewer and fewer, overtaken in frequency by ceasefire agreements. While the increase in local agreements may be a by-product of better data collection methods and increased public relations and information activities on the part of the international third parties, the decline of pre-negotiation agreements and broader intrastate agreements is evident even as data collection methods improve. All of this suggests a change in the way that peacemaking activities take place that, in turn, requires further upgrades in data collection to be made, in order to better capture subnational and subregional agreements, as will be further discussed below.

\section{Agreement into data: how PA-X is made}

The process through which a peace agreement document becomes part of the PA-X database consists of three parts: cataloguing, decision on publication, and data coding and entry. As the database also serves as an archive of agreements, each document is catalogued, uploaded to the database in pdf format, translated, and transcribed into plain text, so that it may be machine readable. At that point, the decision is made on whether a document qualifies as a peace agreement, according to criteria outlined above - and if it does, it is assigned to a human coder for data entry. Over the years, most of the coding was done by the core PA-X team, ${ }^{14}$ guided by the coding manual initially developed by Christine Bell, and expanded with the team's support. It is important to note that the PA-X coding team has been cross-disciplinary and multilingual, composed of legal scholars and political scientists with regional expertise. The reliability of the data is ensured by joint team discussions of any uncertain issues in data coding; decisions made on any borderline issues are both recorded in the coding manual and are available to access by using a Q\&A function on the database back end. This function enables coders to refer a question to the lead investigator, whose response is then recorded alongside the question and is made available to all coders. All agreements in a new batch are catalogued and uploaded and all the data are entered and there are 271 data points to be entered for each agreement, with additional 53 and 30 parameters to be entered in PA-X Gender and PA-X Local, respectively. Once that is 
done, a data release is scheduled. As new additions to PA-X are done in batches of 20 to 50 agreements, releases are planned at least once a year, with current plans for maintaining and updating the database extending through 2026.

Producing a data resource is also a process of learning and developing best practices for data collections, management, and dissemination. In terms of lessons for data management and preservation of integrity and reliability of the data, the mechanisms for recording decisions have been vital. This helps clarify the extent of variation found in peace negotiation practice, as each new release leads to new questions and new issues that arise in the process of classifying the agreement provisions, often prompting additions to the coding manual. The record of decisions contained in the manual has become a most valuable resource for the maintenance of the data. Surprisingly, the process is also instructive in terms of designing user interfaces - an area that is important, but often marginalised by simple data provision via download that characterises most publicly available datasets in the social sciences.

Figure 3. "Messy Timelines": an overview of meandering nature of peace processes ${ }^{15}$

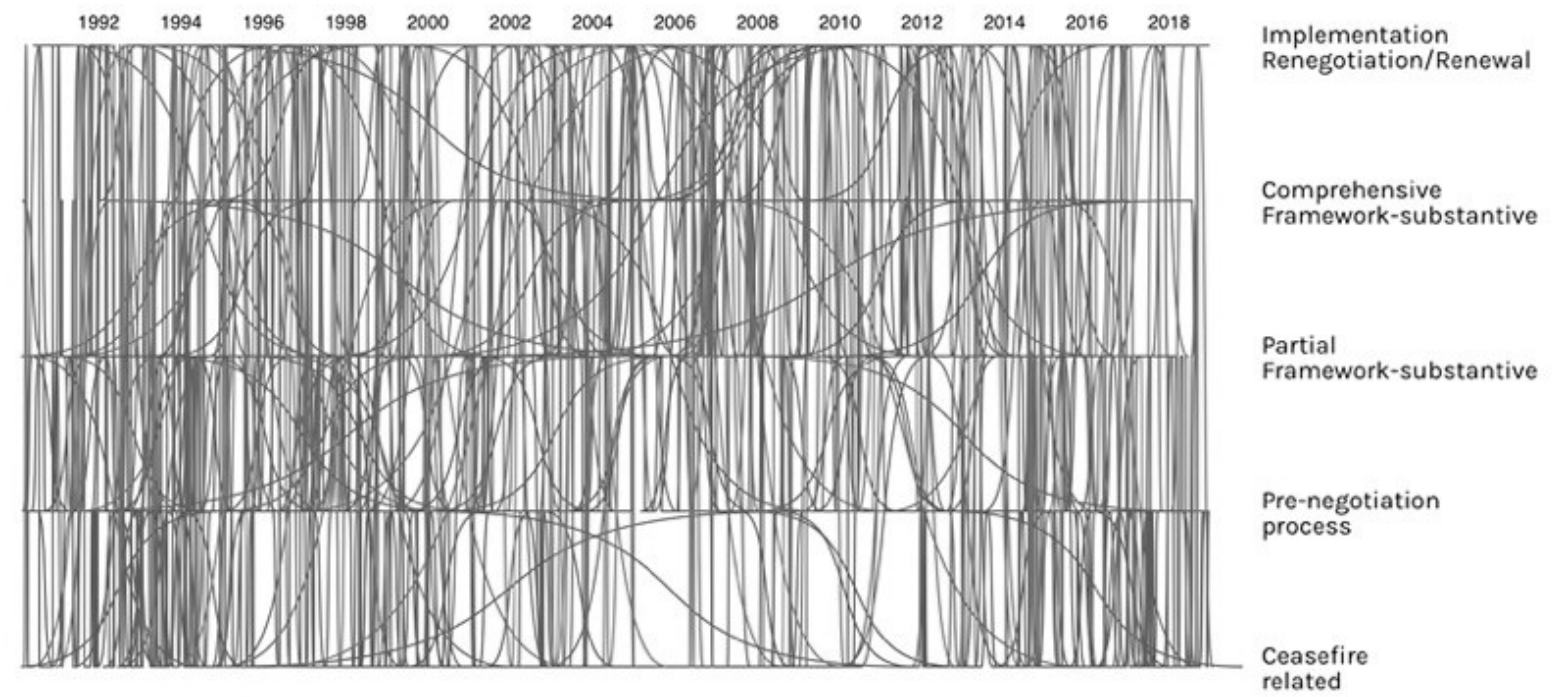

The lessons on data dissemination and user interfaces gleaned from the PA-X working process have been somewhat surprising, from the point of the core purposes with which various users approach the data and web interface. The initial thinking behind the web search design aimed at providing users with options to choose from. Having been aware of the variety of foci in the study of peace agreements, the PA-X team wanted to provide users a way to access the data that would allow all to craft the search results as they saw fit. However, while some users approached the data interface in this way, many found it complex and overwhelming, particularly if their interest went beyond looking at data collections for particular countries. For instance, while PA-X contains the largest publicly available collection of formal, written ceasefires, from a user interested in those ceasefire agreements only, to get to this collection, it is required to make selections on the "Advanced search" page, and then find his/her way to the "Stage" drop-down menu and select "Ceasefires" from there. In sum, it was found that users want simplicity, but the one that nevertheless allows for a wide range of choices. The next stage of PA-X development will feature simplified search tools and designated pages for specific PA-X Collections, such as datasets on ceasefires, interstate agreements, agreements that form interim arrangements, and the like. 
The requirement of simple access to data does not mean that PA-X should be reduced to provide fewer ways to access the data. The data will still be available to download in a variety of formats, including .csv format for the corpus of texts and quantitative datasets. The PA-X team has also come to rely on the data visualisation as a tool that quickly conveys complex ideas (e. g., the messy timeline, as shown by Figure 3) and has added the option of visualising any database search result as an interactive timeline. An additional access point for using and understanding the PA-X data is in the process of being developed: the PA-X API (application programming interface). As the PA-X data were increasingly used in web-based visualisations ${ }^{16}$ (maps, timelines, and graphs of various types) and in applications such as "PeaceFem App", ${ }^{17}$ the need of an API became more apparent, as it could directly feed into the visualisations and apps. The visual representations of data have been important for engagement with audiences that are not strictly academic or research-oriented, and developing such visualisations has become a key part of the PA-X dissemination plans. The API will also assist academic researchers by enabling them to get the most recent release of PA-X data directly from the data source via their data analysis software.

\section{PA-X in comparison and use}

PA-X is by no means the only resource that provides data and information on peace agreements. It can be seen as complementing other resources, functionalities and aims of which overlap substantially across the databases and datasets. The main resources on peace agreements include the Peace Accords Matrix (PAM), ${ }^{18}$ Uppsala Conflict Data Programme (UCDP) Peace Agreements Dataset, ${ }^{19}$ "Language of Peace", 20 the "United Nations Peacemaker", ${ }^{21}$ United States Institute for Peace (USIP) Peace Agreements collection, ${ }^{22}$ Political Agreements in Internal Conflict (PAIC), ${ }^{23}$ and ETH/UCDP/PRIO Ceasefires. ${ }^{24}$ These datasets are compared in Table 2 below.

PA-X shares some features with each of these resources. Like "Language of Peace", the USIP collection, and the "UN Peacemaker", PA-X is striving to be the repository of agreements, allowing practitioners and qualitative researchers an easy access point to the full texts and key metadata and provisions. The main advantage of the PA-X database, as compared to these three resources, is in the wider scope of agreements: for instance, PA-X contains almost twice the number of documents available from the "UN Peacemaker" or "Language of Peace" (see Table 2). A further advantage of PA-X is the ability to make detailed searches on the PA-X website and download the data as filtered by the search. Finally, PA-X provides English-language translations of all agreements, as well as the documents in the original language, a feature missing from the "Language of Peace" collection, which comes closest to PA-X's scope. Translations have been done by professional translators and in some cases by native speakers who are also project specialists on the PA-X team, which makes PA-X a unique English-language resource for studying peacemaking.

As a quantitative data resource, PA-X is most similar to the UCDP, PAM, and PAIC collections that provide download points for quantitative datasets that cover the metadata and substantive provisions. ${ }^{25}$ Among these, the PAM database differs the most from PA-X and other datasets in terms of scope and aims, as it contains the main comprehensive agreements since 1990 and follows the implementation of key provisions. While the PAM database places an emphasis on the complexities of implementation of comprehensive agreements, PAIC focuses on key political agreements, and the UCDP Peace Agreements Database is limited to accords resolving incompatibilities between warring sides, PA-X emphasises the complex path taken prior 
to comprehensive settlements (and often the path after such settlements break down). The reality of peace processes as non-linear and messy (as discussed above and illustrated by Figure 3) is well reflected by the PA-X database: the temporal ordering of agreements in a particular conflict can demonstrate the difficult path of conflict resolution. Additionally, PA-X is the only resource that provides peace agreements as a downloadable corpus of texts, facilitating text-as-data research on peace agreements and peace processes.

The PA-X dataset is also constructed with the aim of supporting research on armed conflict and peacemaking efforts and can be seen as complementing the data provided by the UCDP, the "Correlates of War" (CoW) project, and Armed Conflict Location and Event Dataset (ACLED) ${ }^{26}$ databases on armed conflicts and violence. Thus, the PA-X dataset uses the UCDP conflict codes, ${ }^{27} \mathrm{CoW}$ war numbers, ${ }^{28}$ and the $1 S O 3^{29}$ and Gleditsch-Ward ${ }^{30}$ country codes. With these identification codes included for each agreement, researchers using quantitative data can aggregate and merge the PA-X data with any conflict- or country-level dataset. These features should be considered in conjunction with the PA-X website and search tool, where users can set the parameters of the data in which they are interested and download a customised data file. For instance, anyone interested in interstate agreements, or agreements concerning countries in Africa, or local agreements in Nepal can use the search function to download a quantitative data file or corpus of agreements that match their requirements.

The manner in which the PA-X data have been used over the years since its 2018 release confirms the importance of providing multiple access points and data formats: both qualitative and quantitative scholars have relied on PA-X in their work, and it has supported the development of the conceptual understanding of agreements, ceasefires, and their role in peace processes. Research based on PA-X has yielded interesting work on trends in agreement content: for example, C.Bell and K.McNicholl assessed the extent to which peace agreements have adopted a gender perspective, ${ }^{31}$ and R.Forster used the PA-X agreements to study implementation of mine action provisions. ${ }^{32}$

Excellent examples of the use of PA-X in qualitative research come from A.Jamar, ${ }^{33}$ B.Coe and K.Nash, ${ }^{34}$ and C.Lacatus and K.Nash. ${ }^{35}$ Jamar, for instance, uses the PA-X data as a basis for a qualitative study of how victims and victimhood are framed in peace agreements, examining specific provisions in detail through a custommade qualitative coding procedure provided by "NVivo" software. ${ }^{36}$ Coe and Nash focus on the role of regional and subregional organisations in Africa and their activities related to promotion of peace and security. They have added coding to 294 agreements from PA-X to assess these organisations' roles. Lacatus and Nash assess the arrangements for safeguarding human rights found in a subset of 126 PA-X agreements. They discover that human rights most often end up localised in the hands of national institutions, with little reliance on international human rights regimes. PA-X is also used as a source for peace agreement documents in legal analysis, as done by M.Sosnowski ${ }^{37}$ and by M.Adhikari in her analysis of peacebuilding processes. ${ }^{38}$

There have been fewer examples of the use of PA-X in quantitative literature on peace and conflict, with some notable exceptions. For example, G.Clayton and V.Sticher ${ }^{39}$ use PA-X as a quantitative resource, further sub-coding the ceasefires to show that ceasefire agreements vary in type and extent of bargaining issues they aim to resolve, and as such face different odds of survival. A.Duursma ${ }^{40}$ uses PA-X in conjunction with the UCDP Peace Agreements Dataset and the "UN Peacemaker" to compile a dataset on negotiated settlements for the dyad-year data units. This dataset is used to reassess the role of African third parties in mediation. PA-X is also relied upon as a source on shifting the conceptual debates on peace processes and non-formalized 
attempts to end conflicts or put them on pause, particularly in relation to successful linkage between concept and measurement. Y.Kapshuk, ${ }^{41}$ for instance, develops the concept of peace process, showing that both PA-X and other data resources ought to take better account of the difficulties in determining peace process boundaries.

When it comes to providing research data, PA-X has achieved its main aim, both in terms of qualitative and quantitative data it provides. It is regularly relied upon in a variety of research projects. However, as the research field moves forward, demanding more detailed and more disaggregated data, PA-X needs to expand to keep up. In the next section, four main areas are explored where the PA-X data should be improved to better match the on-the-ground attempts to make peace and resolve conflict.

\section{What have we learned and where do we go from here?}

There is a conceptual consistence in the PA-X data: the collection is well bounded by its core criteria: formal, signed, written agreements in armed conflicts, reached in the period since 1990. However, there is a tendency to understand the data as a collection of peace process outcomes, and to an extent, this is an acceptable way to think of the PA-X data, although not fully. When it comes to data on peace processes, PA-X, indeed, comes the closest to providing a comprehensive, comparative, consistent data resource on peace process progression or lack thereof. Nevertheless, even though PA-X comes close enough, it does not cover the full extent of information on peace processes, as four components are missing.

First, in practice, many negotiations result in failures and lead to neither formal, nor informal arrangements. If the parties tried to negotiate, but failed, this too ought to be included in some collection of data on peace processes. PA-X, however, does not collect information on such cases. Additionally, attempted talks may be exceedingly difficult to track and record, which puts in question the viability of respective data collection efforts. However, a study of peace processes ought to consider such cases to gain full insight into a variety of attempts to end or pause armed conflict, particularly if the research is focused on gaps between the warring sides on certain contested issues, as a failed attempt to negotiate shows how far the opposing sides' expectations are from each other and often from reality.

Second, negotiations between warring sides may result in informal deals, arrangements announced to the media only, or agreements that are signed but not published. Also, sometimes even failures to engage in talks result in one-sided proclamations and announcements of measures to halt violence. Ceasefires are cases in point: the reports of ceasefires are more common than records of formal agreements that fit the PA-X criteria. The PA-X team found this to be true while compiling the main $P A-X$ database, but also confirmed this observation while developing the "Ceasefires in a Time of Covid-19 Tracker". ${ }^{42}$ During 2020-2021, while collecting formal agreements for PA-X and a variety of ceasefire-related events for the Tracker, the PA-X team found that the ratio of informal or one-sided ceasefire arrangements to formally agreed and written ceasefires is about 2.5:1. This general expectation was further supported by the ETH/UCDP/PRIO Ceasefires data collection effort that lists more than 2000 ceasefires for a period when PA-X finds just 891 (including ceasefire agreements and agreements that contain ceasefire provisions). ${ }^{43}$ To better understand both peace processes and conflict dynamics, analyses ought to include these types of arrangements rather than relying on formal agreements alone.

Third, an in-depth analysis of peace processes, particularly for case study research, could consider a variety of drafts that the negotiating parties produce. These 
drafts contain information on the sides' starting positions, issues that are vital to them, and those on which they may be willing to compromise. However, these documents are difficult to acquire and are likely to be considered and kept confidential, for internal use by actual negotiators. This poses numerous obstacles to research in terms of practical viability across settings and research ethics, as revealing confidential documents may cause harm to those involved in negotiations.

Finally, the difficulty in delineating peace processes is found not only at the start of a process when it may produce informal arrangements and numerous drafts, but also at its conclusion. In many cases, a peace process would continue through legislative and constitution-making measures. In fact, there are many clear instances in which a country's constitution forms the endpoint of a peace process, and as such the constitution is a final comprehensive peace agreement. When a constitution is, indeed, such an endpoint, it is included in PA-X as an agreement. The most recent release of PA-X contains 18 such constitutions. However, it is also possible that efforts to resolve an armed conflict continue through the use of legislative tools which are not covered in PA-X. Most notably, amnesties are often discussed in negotiations, and while some do make it into peace agreements that are signed, many are passed as laws or executive decrees. For instance, the Amnesties, Conflict and Peace Agreement (ACPA) dataset records 289 amnesty processes - and only 115 of them are enacted via a peace agreement. ${ }^{44} \mathrm{~A}$ data resource or research project that is fully dedicated to recording peace process components would also need to include amnesties and other relevant tools of conflict resolution that are enacted in other types of processes.

In addition to matters that concern a broader understanding of peace processes and their place in conflict dynamics and resolution, the data already included in PA-X should be expanded to match the current efforts in political science that require the data resources to be disaggregated. Thus, rather than considering countries and conflicts, the impetus has in recent years turned to more focus on the micropolitics of conflicts and violence (as discussed by K.S.Gleditsch et al.), ${ }^{45}$ with data provided the level of each armed group $^{46}$ and for increasingly more specific locales. ${ }^{47}$ This vector corresponds to the issues found when compiling data in PA-X. When considering agreements as they pertain to particular countries and conflicts, much nuance is lost, as each agreement may only refer to a portion of the national territory or a conflict area in question, and/or reflect a deal among some but not all conflict parties.

There is a potential for PA-X to provide more granular data, as it records the signing parties for all agreements. In addition, the agreements in the PA-X Local subdatabase are all geocoded with a focus on the central point of a relevant area. The next step, to be implemented within the next two years, will be to ground PA-X at the level of signing actors, so that these data can be used alongside data on armed groups. Further planned improvement of the PA-X data is to provide geocoding in the form of a map polygon for each agreement, thus producing more exact geographic data on the agreements. Some of the issues outlined above do not have easy solutions - particularly with regard to recording failed attempts at negotiation and integrating the informal and the post-agreement arrangements. These issues remain a key part of the research agenda for PA-X and will be the object of study by the PA-X team over the next five-year period. 
Table 2. Comparison of key data resources on peace agreements

\begin{tabular}{|c|c|c|c|c|c|c|c|}
\hline Data source & $\begin{array}{l}\text { Number of } \\
\text { agreements }\end{array}$ & $\begin{array}{l}\text { Number of issues } \\
\text { covered in data }\end{array}$ & Aims/focus & $\begin{array}{l}\text { Quanti- } \\
\text { tative } \\
\text { data }\end{array}$ & Types of data output & $\begin{array}{l}\text { Search } \\
\text { tools }\end{array}$ & $\begin{array}{l}\text { Temporal } \\
\text { coverage }\end{array}$ \\
\hline PA-X & 1915 & $\begin{array}{l}244 \text { categories and } \\
\text { subcategories of issues } \\
+27 \text { categories of } \\
\text { metadata }+30 \text { local } \\
\text { issues }+53 \text { issues related } \\
\text { to women/girls/gender } \\
\end{array}$ & $\begin{array}{l}\text { Archives all formal, written, } \\
\text { signed peace agreements and } \\
\text { codes for substantive content }\end{array}$ & Yes & $\begin{array}{l}\text { Qualitative search results by } \\
\text { metadata and issue, quantitative } \\
\text { dataset of issues covered, corpus } \\
\text { of agreement texts, pdfs of } \\
\text { agreements in English and in any } \\
\text { other original language }\end{array}$ & Yes & 1990-2021 \\
\hline PAM & 323 & $\begin{array}{l}207 \text { categories of issues } \\
\text { and their implementation } \\
+9 \text { categories of } \\
\text { metadata }\end{array}$ & $\begin{array}{l}\text { Provides data on } \\
\text { implementation of } \\
\text { comprehensive peace } \\
\text { agreements in internal conflict }\end{array}$ & Yes & $\begin{array}{l}\text { Quantitative dataset, qualitative } \\
\text { search tool }\end{array}$ & Yes & 1989-2015 \\
\hline UCDP PA & 355 & $\begin{array}{l}43 \text { issues } \\
+25 \text { categories of } \\
\text { metadata }\end{array}$ & $\begin{array}{l}\text { Provides data on all } \\
\text { agreements that resolve some } \\
\text { form of incompatibility between } \\
\text { warring sides }\end{array}$ & Yes & $\begin{array}{l}\text { Quantitative dataset and full texts } \\
\text { for most agreements }\end{array}$ & No & 1975-2018 \\
\hline Peacemaker & $\sim 800$ & $\begin{array}{l}7 \text { searchable or sortable } \\
\text { categories }\end{array}$ & $\begin{array}{l}\text { Archives peace agreements } \\
\text { and provides a search tool }\end{array}$ & No & $\begin{array}{l}\text { Qualitative search results by } \\
\text { metadata and issue, text of } \\
\text { document in the original language }\end{array}$ & Yes & 1897-2017 \\
\hline $\begin{array}{l}\text { Language of } \\
\text { Peace }\end{array}$ & $\begin{array}{l}\sim 1000 \text { (incl. } \\
968 \text { not } \\
\text { categorized } \\
\text { as decoloni- } \\
\text { sation } \\
\text { agreements } \\
\end{array}$ & $\begin{array}{l}26 \text { core categories, each } \\
\text { with numerous } \\
\text { subcategories, available } \\
\text { to search }\end{array}$ & $\begin{array}{l}\text { Archives peace agreements } \\
\text { and provides a search tool }\end{array}$ & No & $\begin{array}{l}\text { Qualitative search results by } \\
\text { metadata and issue, text of } \\
\text { document in the original language }\end{array}$ & Yes & 1934-2021 \\
\hline PAIC & 286 & $\begin{array}{l}122 \\
+42 \text { categories of } \\
\text { metadata }\end{array}$ & $\begin{array}{l}\text { Provides detailed coding of } \\
\text { political agreements in internal } \\
\text { conflicts }\end{array}$ & Yes & Quantitative dataset & No & 1989-2016 \\
\hline $\begin{array}{l}\text { USIP Peace } \\
\text { Agreements }\end{array}$ & $\begin{array}{l}\text { Covering } 48 \\
\text { conflicts }\end{array}$ & NA & $\begin{array}{l}\text { Provides key agreements for } \\
48 \text { conflicts }\end{array}$ & No & $\begin{array}{l}\text { Web resource with agreements } \\
\text { lists grouped by country/conflict }\end{array}$ & $\begin{array}{l}\text { Yes - by } \\
\text { country/ } \\
\text { conflict }\end{array}$ & From 1989 \\
\hline $\begin{array}{l}\text { ETH/PRIO/ } \\
\text { UCDP } \\
\text { Ceasefires }\end{array}$ & $2000+$ & NA & $\begin{array}{l}\text { Provides data on formal/written } \\
\text { and other ceasefires }\end{array}$ & Yes & Not yet public - NA & NA & 1989-2020 \\
\hline
\end{tabular}


These concerns, taken together, prompt wider research agenda that is needed for a better understanding of peace processes and call for more effective use of the PA-X data in both qualitative and quantitative studies. The new ceasefires data ${ }^{48}$ will certainly contribute to this, as will the planned extensions of the current PA-X suite of data.

\section{Conclusion}

This article provided an overview of the PA-X Peace Agreements Database and Dataset, currently containing 1915 agreements reached in relation to various conflicts and at various stages of negotiation and signed between 1990 and the present day. As the most extensive record of formal peace agreements for this time period, PA-X has become a valuable resource for scholars studying peacemaking, negotiations, peace processes, and their relation to conflict dynamics. However, to be able to further contribute to these fields of study, PA-X must continue to develop, in terms of its scope and the types of data it provides to the research community. The plans are currently in place to maintain and update PA-X through 2026, develop the API, and to extend it by providing a dataset of commitments made by specific armed actors in peace negotiations and developing a set of map polygon data that will allow for more detailed and granular examination of agreement geographies. However, the difficult task of providing data that comprehensively cover all aspects of peace processes remains the key challenge and opportunity for the future development of PA-X as a data resource for social scientists.

\section{ENDNOTES}

\footnotetext{
${ }^{1}$ Bell C., Badanjak S., Beaujouan J., Forster R. et al. PA-X Codebook: Women, Girls, and Gender. Version 4. Edinburgh: Political Settlements Research Programme, University of Edinburgh, 2020. URL: https://www.peaceagreements.org/files/WGG_codebook_June2020.pdf (accessed 07.11.2021).

2 Bell C., Adhikari M., Badanjak S., Beaujouan J. et al. PA-X Local Peace Agreements Database and Dataset, Version 1. - Edinburgh: Political Settlements Research Programme, University of Edinburgh, 2021. URL: https://www.peaceagreements.org/files/PAX_Local_codebook.pdf (accessed 07.11.2021).
}

${ }^{3}$ Bell C., Badanjak S., Beaujouan J., Epple T. et al. PA-X Peace Agreements Database and Dataset. Version 5. Edinburgh: Political Settlements Research Programme, University of Edinburgh, 2021. P. 2. URL: https://www.peaceagreements.org/files/PA-X_codebook_Version5.pdf (accessed 07.11.2021). See also Bell C., Badanjak S. Introducing PA-X: a new peace agreement database and dataset // Journal of Peace Research. 2019. V. 56. № 3. P. 452-466.

${ }^{4}$ Peace Agreements Database. URL: https://www.peaceagreements.org/search (accessed 06.11.2021).

${ }^{5}$ See Treaty on the Final Settlement with Respect to Germany (Four plus Two Agreement) // Peace Agreements Database. URL: https://www.peaceagreements.org/view/1887 (accessed 06.11.2021).

${ }^{6}$ Bell C., Badanjak S., Beaujouan J., Forster R. et al. Op cit.

${ }^{7}$ Bell C., Adhikari M., Badanjak S., Beaujouan J. et al. Op. cit.

8 PA-X Women, Girls, and Gender (PA-X Gender) Database // Peace Agreements Database. URL: https://www.peaceagreements.org/wsearch; Search the Peace Agreements Database (Local Agreements) // Peace Agreements Database. URL: https://www.peaceagreements.org/Isearch (both accessed 06.11.2021). 
9 Bell C. On the Law of Peace: Peace Agreements and the Lex Pacificatoria. - Oxford: Oxford University Press, 2008.

10 Allison J., Badanjak S., Bach B., Bell C., Bhattacharya D., Knaussel F., Wise L. An interactive tracker for ceasefires in the time of COVID-19 // The Lancet Infectious Diseases. 2021. V. 21. № 6. P. 764-765.

${ }^{11}$ Russell I., Wise L., Badanjak S. VaxxPax: a dataset of vaccination ceasefires // Edinburgh DataShare. 2021. URL: https://datashare.ed.ac.uk/handle/10283/4018 (accessed 06.11.2021).

12 See all Great Lakes agreements at: Peace Agreements Database.

URL: http://www.peaceagreements.org/searchadv?SearchForm[region][]=1\&SearchForm [country_entity][] =6\&SearchForm[agreement_type][]=Interstate/intrastate+conflict(s)\&SearchForm[name]=\&SearchForm[date_ after]=\&SearchForm[date_before]=\&SearchForm[category_mode]=any\&SearchForm[agreement_text]=\&Searc hForm[version]=\&s=Search+Database (accessed 06.11.2021).

${ }^{13}$ Bell C. Op. cit. P. 56.

14 Bell C., Badanjak S., Beaujouan J., Epple T. et al. Op. cit.

15 This is a still image of an interactive plot available at: Visualizing peace: messy timeline // Peace Agreements Database. URL: https://www.peaceagreements.org/visualizing-peace?visualisation=messy (accessed 06.11.2021).

16 Havens L., Pschetz L., Bell C., Bao M., Bach B. PaxVis: visualizing peace agreements // CHI EA '19: Extended Abstracts of the $2019 \mathrm{CHI}$ Conference on Human Factors in Computing Systems. May 2019. Paper No. LBW0268. P. 1-6.

17 This app is available for smartphones and provides examples of women's inclusion in peace processes and provisions related to women and gender found in a variety of peace agreements. For more detail about the "PeaceFem App", see: PeaceFem App. Political Settlements Research Programme. URL: https://www.politicalsettlements.org/peacefem (accessed 06.11.2021).

18 Joshi M., Quinn J.M., Regan P.M. Annualized implementation data on comprehensive intrastate peace accords, 1989-2012 // Journal of Peace Research. 2015. V. 52. № 4. P. 551-562.

19 Högbladh S. Peace agreements 1975-2011: updating the UCDP Peace Agreement Dataset // States in Armed Conflict 2011. Department of Peace and Conflict Research Report 99. Eds. Th.Pettersson and L.Themnér. Uppsala: Uppsala University: 2012. P. 39-56; Pettersson T., Öberg M. Organized violence, 1989-2019 // Journal of Peace Research. 2020. V. 57. № 4. P. 597-613.

20 Language of Peace Database. URL: https://www.languageofpeace.org (accessed 06.11.2021).

${ }^{21}$ UN Peacemaker Peace Agreements Database search. URL: https://peacemaker.un.org/document-search (accessed 06.11.2021).

22 Peace Agreements Digital Collection. United States Institute of Peace. 15 April 2009. URL: https://www.usip.org/publications/2009/04/peace-agreements-digital-collection (accessed 06.11.2021).

${ }^{23}$ Fontana G., Kartsonaki A., Neudorfer N.S., Walsh D., Wolff S., Yakinthou C. The dataset of Political Agreements in Internal Conflicts (PAIC) // Conflict Management and Peace Science. 2020. V. 38. № 3. P. 338364. 
${ }^{24}$ Clayton, G., Nygård H.M., Rustad S.C.A., Wiehler C., Sagård T., Landsverk P., Ryland R., Sticher V., Wink E., Bara C. Introducing the ETH/PRIO Civil Conflict Ceasefire Dataset. ETH (Eidgenössische Technische Hochschule Zürich) Working Paper. - Zurich: ETH, 2021 (forthcoming).

25 The PA-X data downloads contain the UCDP and PAM agreement identification codes, so that any interested researchers can merge and match the available data from these resources. The PAIC agreement identification codes will be added to PA-X in 2022.

${ }^{26}$ Raleigh C., Linke A., Hegre H., Karlsen J. Introducing ACLED: an armed conflict location and event dataset // Journal of Peace Research. 2010. V. 47. № 5. P. 651-660.

27 Pettersson T., Öberg M. Op. cit.

${ }^{28}$ Sarkees M.R., Wayman F.W. Resort to War: A Data Guide to Inter-state, Extra-state, Intra-state, and Non-state Wars, 1816-2007. Correlates of War Series. - Washington D.C.: CQ Press, 2010.

${ }^{29}$ ISO 3166-1 alpha-3 codes are three-letter country codes defined in ISO 3166-1, part of the ISO 3166 standard published by the International Organization for Standardization (ISO), to represent countries, dependent territories, and special areas of geographical interest.

30 Gleditsch K.S., Ward M.D. Interstate system membership: a revised list of the independent states since 1816 // International Interactions. 1999. V. 25. № 4. P. 393-413.

${ }^{31}$ Bell C., McNicholl K. Principled pragmatism and the "Inclusion Project": implementing a gender perspective in peace agreements // Feminists@Law. 2019. V. 9. № 1. P. 1-51.

32 Forster R. Twenty years after Ottawa: "unpacking" mine action in peace agreements // Journal of Peacebuilding and Development. 2019. V. 14. № 2. P. 150-163.

33 Jamar A. The exclusivity of inclusion: global construction of vulnerable and apolitical victimhood in peace agreements // International Journal of Transitional Justice. 2021. V. 15. № 2. P. 284-308.

${ }^{34}$ Coe B., Nash K. Peace process protagonism: the role of regional organisations in Africa in conflict management // Global Change, Peace and Security. 2020. V. 32. № 2. P. 157-177.

35 Lacatus C. and Nash K. Peace agreements and the institutionalisation of human rights: a multi-level analysis // International Journal of Human Rights. 2020. V. 24. № 6. P. 889-912.

36 "NVivo" is data analysis software package developed by "QSR International". It helps manage and organize unstructured or qualitative data.

37 Sosnowski M. "Not dead but sleeping": expanding international law to better regulate the diverse effects of ceasefire agreements // Leiden Journal of International Law. 2020. V. 31. № 3. P. 731-743.

38 Adhikari M. Peacebuilding with "Chinese characteristics"? Insights from China's engagement in Myanmar's peace process // International Studies Review. 2021. Viab039. P. 1-28.

${ }^{39}$ Clayton G., Sticher V. The logic of ceasefires in civil war // International Studies Quarterly. 2021. V. 65 . № 3. P. 633-646.

40 Duursma A. African solutions to African challenges: the role of legitimacy in mediating civil wars in Africa // International Organization. 2020. V. 74. № 2. P. 295-330. 
${ }^{41}$ Kapshuk Y. Conceptual ambiguity in coding the categories of peace agreement and peace process // Peace Economics, Peace Science, and Public Policy. 2021. V. 27. № 1. P. 3-27.

42 Allison et al. Op. cit. The tracker is publicly available and can be accessed at: Ceasefires in a time of COVID-19 // Peace Agreements Database. URL: https://pax.peaceagreements.org/static/covid19ceasefires (accessed 07.11.2021).

43 Clayton, G., Nygård H.M., Rustad S.C.A., Wiehler C. et al. Op. cit.

44 Mallinder L. Amnesty, Human Rights and Political Transitions: Bridging the Peace and Justice Divide. Oxford: Hart Publishing, 2008; Mallinder L. Amnesties and Inclusive Political Settlements. PA-X Report. Transitional Justice Series. - Edinburgh: University of Edinburgh, 2018. URL: https://www.politicalsettlements. org/wp-content/uploads/2018/12/2018_Mallinder_Amnesties-Report.pdf (accessed 07.11.2021). The database is publicly available at: Amnesties, Conflict and Peace Agreement (ACPA) dataset // Peace Agreements Database. URL: https://www.peaceagreements.org/ amnesties (accessed 07.11.2021).

${ }^{45}$ Gleditsch K.S., Metternich N.W., Ruggeri A. Data and progress in peace and conflict research // Journal of Peace Research. 2014. V. 51. № 2. P. 301-314.

${ }^{46}$ Lutmar C., Terris L.G. Introducing a new dataset on leadership change in rebel groups, 1946-2010 // Journal of Peace Research. 2019. V. 56. № 2. P. 306-315; Otto S., Scharpf A., Gohdes A.R. Capturing group alignments: introducing the Government and Armed Actors Relations Dataset (GAARD) // Research and Politics. 2020. V. 7. № 4. P. 1-8; Cohen D.K., Nordås R. Sexual violence in armed conflict: introducing the SVAC dataset, 1989-2009 // Journal of Peace Research. 2014. V. 51. № 3. P. 418-428.

47 Sundberg R., Melander E. Introducing the UCDP Georeferenced Event Dataset // Journal of Peace Research. 2013. V. 50. № 4. P. 523-532; Croicu M., Sundberg R. UCDP GED Codebook Version 4.0. - Uppsala: Uppsala University, 2015.

${ }^{48}$ Clayton G., Nygård H.M., Rustad S.C.A., Wiehler C. et al. Op. cit.

\section{BIBLIOGRAPHY}

Adhikari M. (2021). Peacebuilding with "Chinese characteristics"? Insights from China's engagement in Myanmar's peace process. International Studies Review. Viab039. P. 1-28. DOI: 10.1093/isr/viab039.

Allison J., Badanjak S., Bach B., Bell C., Bhattacharya D., Knaussel F., and Wise L. (2021). An interactive tracker for ceasefires in the time of COVID-19. The Lancet Infectious Diseases. V. 21. No. 6. P. 764-765. DOI: 10.1016/S1473-3099(20)30932-4.

Bell C. (2008). On the Law of Peace: Peace Agreements and the Lex Pacificatoria. Oxford: Oxford University Press. 200 p. DOI: 10.1093/acprof:oso/9780199226832.001.0001.

Bell C., Adhikari M., Badanjak S., Beaujouan J., Distrotti M., Epple T., Forster R., Wilson R., and Wise L. (2021). PA-X Local Peace Agreements Database and Dataset, Version 1. Edinburgh: Political Settlements Research Programme, University of Edinburgh. 22 p.

URL: https://www.peaceagreements.org/files/PAX_Local_codebook.pdf (accessed 07.11.2021).

Bell C. and Badanjak S. (2019). Introducing PA-X: a nēw peāe agreement database and dataset. Journal of Peace Research. V. 56. No. 3. P. 452-466. DOI: 10.1177/0022343318819123.

Bell C., Badanjak S., Beaujouan J., Forster R., Epple T., Jamar A., McNicholl K., Molloy S., Nash K., Pospisil J., Wilson R., and Wise L. (2020). PA-X Codebook: Women, Girls, and Gender. Version 4. Edinburgh: Political Settlements Research Programme, University of Edinburgh. 11 p. URL: https://www.peaceagreements.org/files/WGG_codebook_June2020.pdf (accessed 07.11.2021).

Bell C., Badanjak S., Beaujouan J., Epple T., Forster R., Jama A., Molloy S., McNicholl K., Nash K., Pospisil J., Wilson R., and Wise L. (2021). PA-X Peace Agreements Database and Dataset, Version 5. Edinburgh: Political Settlements Research Programme, University of Edinburgh. 
71 p. URL: https://www.peaceagreements.org/files/PA-X_codebook_Version5.pdf (accessed 07.11.2021).

Bell C. and McNicholl K. (2019). Principled pragmatism and the "Inclusion Project": implementing a gender perspective in peace agreements // Feminists@Law. 2019. V. 9. No.1. P.1-51. DOI: 10.22024/UniKent/03/fal.742.

Clayton G., Nygård H.M., Rustad S.C.A., Wiehler C., Sagård T., Landsverk P., Ryland R., Sticher V., Wink E., and Bara C. (2021). Introducing the ETH/PRIO Civil Conflict Ceasefire Dataset. ETH (Eidgenössische Technische Hochschule Zürich) Working Paper. Zurich: ETH. Forthcoming.

Clayton G. and Sticher V. (2021). The logic of ceasefires in civil war. International Studies Quarterly. 2021. V. 65. No. 3. P. 633-646. DOI: 10.1093/isq/sqab026.

Cohen D.K. and Nordås R. (2014). Sexual violence in armed conflict: Introducing the SVAC dataset, 1989-2009. Journal of Peace Research. 2014. V. 51. No. 3. P. 418-428.

DOI: $10.1177 / 0022343314523028$.

Coe B. and Nash K. (2020). Peace process protagonism: the role of regional organisations in Africa in conflict management. Global Change, Peace and Security. V. 32. No. 2. P. 157-177. DOI: $10.1080 / 14781158.2020 .1777094$.

Croicu M. and Sundberg R. (2015). UCDP GED Codebook Version 4.0. Uppsala: Uppsala University. $39 \mathrm{p}$.

Duursma A. (2020). African solutions to African challenges: the role of legitimacy in mediating civil wars in Africa. International Organization. V. 74. No. 2. P. 295-330. DOI: $10.1017 / \mathrm{s} 0020818320000041$.

Fontana G., Kartsonaki A., Neudorfer N.S., Walsh D., Wolff S., and Yakinthou C. (2020). The dataset of Political Agreements in Internal Conflicts (PAIC). Conflict Management and Peace Science. V. 38. No. 3. P. 338-364. DOI: $10.1177 / 0738894220944123$.

Forster R. (2019). Twenty years after Ottawa: "unpacking" mine action in peace agreements. Journal of Peacebuilding and Development. 2019. V. 14. No. 2. P. 150-163. DOI: $10.1177 / 1542316619846826$.

Gleditsch K.S., Metternich N.W., and Ruggeri A. (2014). Data and progress in peace and conflict research. Journal of Peace Research. V. 51. No. 2. P. 301-314. URL: $10.1177 / 0022343313496803$.

Gleditsch K.S. and Ward M.D. (1999). Interstate system membership: a revised list of the independent states since 1816. International Interactions. V. 25. No. 4. P. 393-413.

Havens L., Pschetz L., Bell C., Bao M., and Bach B. (2019). PaxVis: visualizing peace agreements. CHI EA '19: Extended Abstracts of the 2019 CHI Conference on Human Factors in Computing Systems. May 2019. Paper no. LBW0268. P. 1-6. DOI: 10.1145/3290607.3313070.

Högbladh S. (2012). Peace agreements 1975-2011: Updating the UCDP Peace Agreement Dataset // States in Armed Conflict 2011. Department of Peace and Conflict Research Report no. 99. Eds. Th.Pettersson and L.Themnér. Uppsala: Uppsala University. P. 39-56.

Jamar A. (2021). The exclusivity of inclusion: global construction of vulnerable and apolitical victimhood in peace agreements. International Journal of Transitional Justice. V. 15. No. 2. P. 284-308. DOI: 10.1093/ijt//ijab014.

Joshi M., Quinn J.M., and Regan P.M. (2015). Annualized implementation data on comprehensive intrastate peace accords, 1989-2012. Journal of Peace Research. V. 52. No. 4. P. 551-562. DOI: $10.1177 / 0022343314567486$.

Kapshuk Y. (2021). Conceptual ambiguity in coding the categories of peace agreement and peace process. Peace Economics, Peace Science, and Public Policy. V.27. No. 1. P. 3-27. DOI: $10.1515 /$ peps-2020-0003.

Lacatus C. and Nash K. (2020). Peace agreements and the institutionalisation of human rights: a multi-level analysis. International Journal of Human Rights. V. 24. No. 6. P. 889-912. DOI: 10.1080/13642987.2019.1690467.

(2021) Language of Peace Database. URL: https://www.languageofpeace.org (accessed 06.11.2021).

Lutmar C. and Terris L.G. (2019). Introducing a new dataset on leadership change in rebel groups, 1946-2010. Journal of Peace Research. V. 56. No. 2. P. 306-315.

DOI: $10.1177 / 0022343318802979$.

Mallinder L. (2018). Amnesties and Inclusive Political Settlements. PA-X Report. Transitional Justice Series. Edinburgh: University of Edinburgh. 79 p. URL: https://www.politicalsettlements.org/wpcontent/uploads/2018/12/2018_Mallinder_Amnesties-Report.pdf (accessed 07.11.2021). 
Mallinder L. (2008). Amnesty, Human Rights and Political Transitions: Bridging the Peace and Justice Divide. Oxford: Hart Publishing. 598 p.

Otto S., Scharpf A., and Gohdes A.R. (2020). Capturing group alignments: introducing the Government and Armed Actors Relations Dataset (GAARD). Research and Politics. V. 7. No. 4. P. 1-8. DOI: 10.1177/2053168020971891.

(2021) Peace Agreements Database: PA-X. Edinburgh: Political Settlements Research Programme, University of Edinburgh. URL: https://www.peaceagreements.org (accessed 06.11.2021).

(2009) Peace Agreements Digital Collection. United States Institute of Peace. 15 April. URL: https://www.usip.org/publications/2009/04/peace-agreements-digital-collection (accessed 06.11.2021).

Pettersson T. and Öberg M. (2020). Organized violence, 1989-2019. Journal of Peace Research. V. 57. No. 4. P. 597-613. DOI: $10.1177 / 0022343320934986$.

Raleigh C., Linke A., Hegre H., and Karlsen J. (2010). Introducing ACLED: an armed conflict location and event dataset. Journal of Peace Research. V. 47. No. 5. P. 651-660. DOI: $10.1177 / 0022343310378914$.

Russell I., Wise L., and Badanjak S. (2021). VaxxPax: a dataset of vaccination ceasefires. University of Edinburgh Law School. DOI: 10.7488/ds/3131. Edinburgh DataShare [Web-site]. URL: https://datashare.ed.ac.uk/handle/10283/4018 (accessed 06.11.2021).

Sarkees M.R. and Wayman F.W. (2010). Resort to War: A Data Guide to Inter-state, Extra-state, Intrastate, and Non-state Wars, 1816-2007. Correlates of War Series. Washington, D.C.: CQ Press. $577 \mathrm{P}$.

Sosnowski M. (2020). "Not dead but sleeping": expanding international law to better regulate the diverse effects of ceasefire agreements. Leiden Journal of International Law. V. 33. No. 3. P. 731-743. DOI: 10.1017/S0922156520000308.

Sundberg R. and Melander E. (2013). Introducing the UCDP Georeferenced Event Dataset. Journal of Peace Research. V. 50. No. 4. P. 523-532. DOI: 10.1177/0022343313484347.

(2021). UN Peacemaker Peace Agreements Database Search. URL: https://peacemaker.un.org/ document-search (accessed 06.11.2021). 